\title{
Interactions between Human and Computer Networks: EFL College Students Using Computer Learning Tools in Remedial English Classes
}

\author{
Ai-Ling Wang \\ English Department, Tamkang University, \\ 151 Yingzhuan Road, Danshui District \\ New Taipei City, Taiwan \\ wanga@mail.tku.edu.tw
}

\begin{abstract}
This study aims to explore how EFL college students perceive some educational computer programs in terms of their effectiveness in learning, their user friendliness, and the role these computer programs can play in students' learning process. Online language learning was viewed from a marketing service perspective. The researcher collected data from the online remedial English classes she offered. Students taking the course are low-achieving language learners. Qualitative data were collected from online interactions between students and students and between students and the teaching assistants or the teacher, interviews with the students, questionnaires filled out and documents submitted online by the students. Data collected for the study were analyzed according to the procedure specified in the grounded theory, including data collection, note-taking, coding, memoing, sorting, and writing. Findings of this study showed that there is a gap between how low-achieving EFL college students and language teachers view computer learning programs.
\end{abstract}

Keywords: educational computer programs, online remedial English class, grounded theory.

\section{Introduction}

In the educational arena, research on e-learning is always done from the teacher's perspective. For example, research studies might focus on how a teacher can develop an online course and how a teacher can interact with students online [1]. This study aims to explore some issues relevant to e-learning from students' perspectives. That is, the researcher intends to investigate how students perceive online learning and how they use the computer to interact with the teacher, teaching assistants, and their fellow learners online. By doing so, the researcher expects to bridge the gap between the teacher and the student.

On the other hand, instead of using the traditional ways of hypothesis-testing in education, this study employed the grounded theory commonly used in the management field to allow significant facts to emerge and to generate possible theories. Looked at from the management perspective, education may be compared to 
business transaction. In this scenario, students may be viewed as customers and online instruction is the product. As the innovator, the teacher has to be aware of students' needs in order to meet their full satisfaction. That is, to bridge the gap between teacher and student, the teacher has to well capture students' needs, interests, characteristics, and their interactions online in order to "market" the "online product" [2][3].

\subsection{Background of the Study}

Since English proficiency has become more and more important in an age moving toward a global village, Tamkang University in Taiwan has set a threshold of English proficiency that requires its students to pass the threshold before they can graduate. For those who are not able to pass the threshold before they graduate, they are allowed to take "online tutorial English" as an alternative.

"Online tutorial English" is offered exclusively for those who are graduating and who have not passed the threshold of English proficiency test. Participants involved in this study are in different levels and different fields of study. Students may be enrolled in the class by showing their records of English proficiency test. Students taking the course meet only in the first week of the semester and the weeks before the mid-term and the final exam. For the rest of the semester, students study English online on their own. There are educational computer programs developed for online learning. The instructor, also the researcher, posted articles on the Web for students to read each week. Each article is accompanied by a PowerPoint file that list and explain some vocabulary words, idioms, and sentences. At the end of the file, there are quizzes, and students are required to do the quizzes online. Students' performance of this course is evaluated based on their mid-term and final exam scores, their responses to the online quizzes, their interactions online, and the length of time they spend online.

\subsection{The Educational Computer Programs and Interactions Online}

There are basically three kinds of educational computer programs used in the study, namely WebCT, Moodle, and the instructional computer platform developed by Tamkang University. All the three educational computer programs share some essential functions, namely posting, response, online discussion, submission and correction of assignments, online testing, grading, etc. At the beginning of the semester, the teacher posted the class requirements and rules, syllabi, grouping, criteria for grading, instruction to the use of educational computer program, etc. The teacher selected articles of different topics for students to read each week. The topics chosen generally covered sports, entertainment, education, culture, health, business, technologies, and some global issues. Students had to read 2 or 3 articles on a certain topic each week. Along with the articles, the teacher also posted a PowerPoint file, explaining some important vocabulary words, sentences, grammar points, and idioms and positing quizzes for students to complete online. The time students spent on the Web was recorded in the program. Students can raise their questions and post them online whenever they want and every member in the "online community" can respond to the questions. After reading the articles, students were asked to do the quizzes 
relevant to the articles and submit their answers online. The teaching assistants will assess their answers and assign a grade to them.

In this research setting, there are different kinds of interaction happening, namely interactions between students and students, students and teaching assistants, students and the teacher, students and the computer, and computer and computer. These online interactions can be great indicators of how students perceive the online course and how the teacher and the teaching assistants may develop an online course to meet students' needs [4].

\section{Methodology}

The researcher roughly followed the principles of grounded theory to conduct the research. The researcher first collected data from different sources, namely different classes of "Online English tutorial", ranging from 2008 to 2010. The qualitative data collected included online instructional materials, students' responses to the online questions, students' written interactions with the teacher, the teaching assistants, and peer students, questionnaires they filled out online, the researcher's field notes and observation, students' written statements handed in to the researcher, and the researcher's interview with students. These data were first coded in the open coding stage. In this stage, the researcher did line-by-line coding and generated some relevant codes. These descriptive codes were then conceptualized and the number of code was reduced on a conceptual coding list. In the coding process of moving from description to conceptualization, the researcher constantly compared between and among incidents, and the emerging concepts were compared with more incidents. Finally, emergent concepts were compared to each other. At the same time, the researcher also did memoing to take some theoretical notes about the conceptual connections between

Table 1. Illustration of Research Paradigm

\begin{tabular}{|l|l|}
\hline $\begin{array}{l}\text { Online remedial } \\
\text { English course }\end{array}$ & Teacher \\
\hline $\begin{array}{l}\text { Instructional } \\
\text { materials }\end{array}$ & $\begin{array}{l}\text { Online reading } \\
\text { materials and reading } \\
\text { instruction }\end{array}$ \\
\hline $\begin{array}{l}\text { Learning tool } \\
\text { the computer) }\end{array}$ & $\begin{array}{l}\text { WebCT } \\
\text { Moodle } \\
\text { School-developed } \\
\text { computer platform }\end{array}$ \\
\hline $\begin{array}{l}\text { Availability and } \\
\text { flexibility }\end{array}$ & $\begin{array}{l}\text { Online learning } \\
\text { (asynchronous) }\end{array}$ \\
\hline Interactivity online & $\begin{array}{l}\text { Functions to post and } \\
\text { respond online } \\
\text { Contact information }\end{array}$ \\
\hline Learning outcome & $\begin{array}{l}\text { Criteria for assessing } \\
\text { students } \\
\text { outcome learning }\end{array}$ \\
\hline
\end{tabular}

Chasm

\begin{tabular}{|l|}
\hline Student \\
\hline Topics \\
Level of difficulty \\
Interests \\
Reading load \\
\hline Familiarity with the \\
program \\
User friendly \\
Functions available \\
\hline Time of learning \\
Accessibility \\
\hline $\begin{array}{l}\text { Channels of interacting } \\
\text { with members of the } \\
\text { online community }\end{array}$ \\
\hline $\begin{array}{l}\text { Value judgment based } \\
\text { on internal and external } \\
\text { motivation }\end{array}$ \\
\hline
\end{tabular}


categories. Then, the researcher sorted the memos to allow a theoretical outline to emerge. As mentioned by Holton [5], this study aims at "explaining" students' online behaviors and their perception of online instruction, rather than just "describing" them.

Based on the coding process mentioned above, the entire research paradigm can be conceptualized and illustrated as follows:

\section{Findings of the Study}

Some significant points have emerged after analysis of the data. First, findings of this study showed that most of the students preferred online instruction to onsite instruction and that only a small number of older students rather than younger students would like to have onsite instruction instead. These older students claimed that they would learn more if they physically attend the class on a regular basis and listen to the teacher explaining some grammar points. Analysis through different levels of coding has shown that older students tend to value classroom learning because they might return to their graduate studies after several years' of working in a certain field. They expect to have direct contact with the teacher and to ask questions and learn from the teacher. In a sense of business transaction, they would expect to get as much as they can for what they have paid. For them, it is a privilege to be formally-educated in a school.

For younger students, they might not have work experiences before and they usually put getting a degree as their top priority. They do not quite value learning in the classroom. In a business sense, they pay in order to get a degree (product). As long as they reach the goal, the deal is done. They are required to complete their scientific or social experiment before they can get their degree. For this reason, they spend most of their time in the lab, working on their research. Online courses provide them with flexibility to manage their time, and they can choose whatever time available for them to go online to learn English. Some of them had to work in the lab on a certain day, and a fixed class schedule would cause inconvenience for them.

Second, another characteristic apparent in the participants' perception of the online course is that most of the students regard English proficiency as an important skill to master; however, they all failed to achieve a certain degree of English proficiency. Analysis of the data showed that they considered English proficiency an important skill because, in an age moving toward a global village, having a good command of English would be a plus in their forthcoming job hunting and would benefit their future career. However, several factors contributed to their failure to master English. Several students claimed that they have a heavy load in their own field of study and they do not have much time and energy to work on improving their English proficiency, especially for those who had to spend most of their time in a lab, doing scientific experiments. Others claimed that they are more inclined to scientific issues than to language and literature. No matter how they spend time learning English, they could not manage to learn the language. The way they perceive their aptitude discourages them to learn English.

Third, still another concept shared by most of the students is that although students attending the remedial class were those who did not pass the threshold of the English 
proficiency test, they did not learn English just because they want to pass the English proficiency test. Some of the students explained that they might need to use English in their future career, such as writing a resume or a cover letter, reading and writing academic papers, and communication in a workplace. As soon as they have a good command of English, they would have no problem passing the English proficiency test. Some of the students took preparatory English proficiency test classes before; however, they claimed that these classes were not of great help. It is because the class size is always large and the class time is always limited.

Fourth, as far as interactions online are concerned, the research data collected showed that only a small part of the students regularly posted or responded on the program system. Analysis of characteristics of these students showed that they cared about their learning of English and about the grade they will earn for this course. Most of them asked the teacher to clarify some grammatical issues they encountered while reading the articles or pointed out some typo errors found in the PowerPoint file. Others reported some technical problems, and still others would question the grade they were assigned by the teaching assistants for the assignment they turned in online. These facts might indicate that students in the remedial English class were not really motivated to learn English if there are no internal or external factors involved in their learning process.

Fifth, generally speaking, findings of the study showed that articles chosen for the course met students' learning need. Most of the students responded that they have little problem reading the articles and that the topics are of their concern. On the other hand, some of the articles with more difficult vocabulary words, such as the one with some medical terms, were also pointed out as being too difficult for low-achieving learners of English. Immediacy to the students is also part of their concern. Some of the students suggested adding "local news" to the list of topics.

Sixth, students seemed to have little problem working on the computer programs. There were only some technical issues reported by the students and these problems were generally solved soon. Students were seen satisfied with the functions available on the computer programs.

\section{Conclusion and Educational Implications}

Based on the theories generated from analysis of this study, the researcher captured a picture of how students perceive online remedial English courses and how they interact online. Generally speaking, students prefer to take remedial English class online because, in this case, they can have flexibility to choose the time available for them to study online. However, this study also showed that there is a gap between teacher's expectation and student's perception of online remedial English course. To bridge the gap, teachers have to take students' perception into account.

Hopefully, this study can provide language teachers who apply modern technologies to their instruction with an insight into how an online course can be best developed to meet students' needs. 


\section{References}

1. Wilkinson, J.S., Wang, A.: Crossing Borders: How Cross-cultural Videoconferencing Can Satisfy Course Goals in Dissimilar Subjects. In: Tseng, P., Kwang, R., Fox, R. (eds.), pp. 109-123. World Scientific Publishing, Singapore (2007)

2. Dick, B.: Grounded theory: a thumbnail sketch (2005), http: / /www.scu.edu.au/schools/gcm/ar/grounded.html

3. Borgatti, S.: Introduction to grounded theory, http: / / www.analytictech.com/mb870/introGT.htm

4. White, C.: Language learning in distance education. Cambridge U.P, Cambridge (2003)

5. Holton, J.A.: The Coding Process and Its Challenges. In: Bryant, A., Charmaz, K. (eds.) The Sage Handbook of Grounded Theory, pp. 265-289. Sage Publications, Thousand Oaks (2007) 